\title{
Suppression of Fusarium Wilt Caused by Fusarium oxysporum f. sp. niveum Race 2 on Grafted Triploid Watermelon
}

\author{
Anthony P. Keinath and Richard L. Hassell, Clemson University, Coastal Research and Education Center, Charleston, SC $29414-5329$
}

\begin{abstract}
Keinath, A. P., and Hassell, R. L. 2014. Suppression of Fusarium wilt caused by Fusarium oxysporum f. sp. niveum race 2 on grafted triploid watermelon. Plant Dis. 98:1326-1332.

Fusarium wilt of watermelon, caused by the soilborne fungal pathogen Fusarium oxysporum f. sp. niveum race 2 , is a serious, widespread disease present in major watermelon-growing regions of the United States and other countries. 'Fascination,' a high yielding triploid resistant to race 1, is grown in southeastern states in fields that contain a mixture of races 1 and 2 . There is some benefit to using cultivars with race 1 resistance in such fields, even though Fascination is susceptible to Fusarium wilt caused by race 2. Experiments in 2012 and 2013 were done in fields infested primarily with race 2 and a mixture of races 1 and 2, respectively. Fascination was grafted onto four rootstock cultivars: bottle gourd (Lagenaria siceraria) 'Macis' and 'Emphasis' and interspecific hybrid squash (Cucurbita maxima $\times$ C. moschata) 'Strong

Tosa' and 'Carnivor.' Nongrafted and self-grafted Fascination were used as susceptible control treatments. In both experiments, mean incidence of plants with symptoms of Fusarium wilt was $\geq 52 \%$ in the susceptible control treatments and $\leq 6 \%$ on the grafted rootstocks. Disease incidence did not differ between rootstock species or cultivars. In both years, Fascination grafted onto Strong Tosa and Macis produced more marketable-sized fruit than the susceptible control treatments. Grafted Emphasis and Carnivor also produced more fruit than the control treatments in 2012. The cucurbit rootstocks suppressed Fusarium wilt caused by race 2 and increased marketable yield of triploid watermelon grown in infested soil.
\end{abstract}

Fusarium wilt of watermelon (Citrullus lanatus var. lanatus (Thunb.) Matsum. \& Nakai) is a serious, widespread disease caused by the soilborne fungal pathogen Fusarium oxysporum $\mathrm{f}$. sp. niveum. Although four races (designated race $0,1,2$, and 3 ) have been reported, race 2 currently is the most destructive race for several reasons (37). Most importantly, race 2 is widely distributed within the United States and is present in most major watermelongrowing regions of the country, including southeastern, southern, Midwestern, and mid-Atlantic states $(15,23)$. Race 2 also is present in other leading watermelon-producing countries, including Turkey, Spain, Republic of Korea, Greece, Tunisia, and Israel $(1,9,19,20,23)$. Second, no diploid (seeded) or triploid (seedless) watermelon cultivars have an intermediate or high level of resistance to race 2, although several diploid cultivars (e.g., 'Allsweet', 'Dixielee', and 'Calhoun Gray') have a low level of resistance relative to cultivars such as 'Crimson Sweet' $(7,36)$. Finally, race 2 is considered a highly virulent race $(23,36)$, in that isolates of race 2 cause rapid, severe wilting of susceptible cultivars. In fields infested primarily with race 2, yield of susceptible, triploid watermelon cultivars can be reduced as much as $69 \%$, based on an expected yield of $45 \mathrm{Mg} / \mathrm{ha}$ for irrigated watermelon cropped with polyethylene mulch $(8,13)$. In Spain, in soil infested with unidentified races of $F$. oxysporum $\mathrm{f}$. sp. niveum, yield loss in a triploid cultivar was 42 to $68 \%$ (25).

Planting cultivars with race 1 resistance in fields infested with a mixture of $F$. oxysporum $\mathrm{f}$. sp. niveum races 1 and 2 reduces the

\section{Corresponding author: A. P. Keinath, E-mail: tknth@clemson.edu}

This material is based upon work supported by NIFA/USDA under project numbers 2011-51181-30963, SC-1700446, and SC-1700366. Technical Contribution Number 6210 of the Clemson University Experiment Station.

* The $e$-Xtra logo stands for "electronic extra" and indicates that Figure 2 appears in color online.

Accepted for publication 8 April 2014.

http://dx.doi.org/10.1094/PDIS-01-14-0005-RE

(C) 2014 The American Phytopathological Society number of wilted plants compared with planting susceptible cultivars $(6,7,15,30)$. 'Fascination' (Syngenta Seeds) is a high-yielding triploid watermelon with intermediate resistance to Fusarium wilt caused by $F$. oxysporum $\mathrm{f}$. sp. niveum race 1 (6). Producers in South Carolina whose fields are infested with races 1 and 2 have begun to plant this cultivar. However, Fascination is susceptible to Fusarium wilt caused by race 2 , as demonstrated when evaluated in Delaware in a field with a mixture of races 1 and $2(6,7)$. New U.S. Plant Introduction genotypes of citron (C. lanatus var. lanatus) with resistance to race 2 were identified recently (34). Until this resistance can be incorporated into triploid watermelon cultivars, additional control measures are needed.

Grafting is a particularly appealing management technique for Fusarium wilt of watermelon. The bottle gourd (Lagenaria siceraria (Molina) Standl.) and interspecific hybrid squash (Cucurbita maxima Duch. ex Lam. $\times C$. moschata Duch. ex Poir) rootstocks used to graft watermelon are resistant to both race 1 and race 2 isolates of the pathogen $(4,14,35)$. Thus, regardless of which race is present or predominates in a field, grafting would protect plants from Fusarium wilt. Grafting also has been shown to be as effective as soil fumigation with methyl bromide or dimethyl disulfide plus chloropicrin in increasing plant survival or reducing Fusarium wilt symptoms $(25,30)$. In a previous study in South Carolina, watermelon grafted onto bottle gourd or interspecific hybrid squash yielded more fruit than nongrafted or self-grafted watermelon when planted in a field infested with $F$. oxysporum $\mathrm{f}$. sp. niveum (14). In Turkey, grafting 'Crimson Tide,' a diploid watermelon cultivar resistant to race 1 , onto bottle gourd increased yields in soil infested with unidentified races of $F$. oxysporum $\mathrm{f}$. sp niveum that included race 2 (35). In Spain, in soil infested with unidentified races of $F$. oxysporum $\mathrm{f}$. sp. niveum, grafting triploid watermelon onto interspecific hybrid squash 'Shintoza' increased yields by over threefold (25).

Because Fusarium wilt is a monocyclic disease, the most effective control measure, from an epidemiological point of view, is to reduce the initial inoculum density (5). Using nonhost rootstocks has the effect of reducing the number of propagules of $F$. oxysporum f. sp. niveum that cause disease. For example, root exudates of bottle gourd rootstocks include chlorogenic acid, which reduced germination of $F$. oxysporum $\mathrm{f}$. sp. niveum conidia (21). In 
most previous studies of grafted watermelon, only the final percentages of surviving plants were published $(25,31)$. The effect of grafting on progression of Fusarium wilt has not been examined. In addition, scions that are susceptible to all races of $F$. oxysporum $\mathrm{f}$. sp. niveum were used although, in Turkey, Crimson Tide was evaluated after grafting onto several cultivars of bottle gourd and interspecific hybrid squash $(14,25,35)$. Often, yields of different rootstocks grafted with the same scion differ from each other $(4,25,35)$. Thus, the yield potential of new scion-rootstock combinations must be tested before they can be recommended to growers. Grafted watermelon plants with Fascination as a scion have not been tested for reaction to Fusarium wilt or yield potential. The overall objective of this study was to evaluate grafting triploid watermelon as a control for Fusarium wilt caused by $F$. oxysporum f. sp. niveum race 2 . The specific objectives were to (i) determine the effect of grafting on progress and severity of Fusarium wilt and (ii) compare yields of grafted triploid watermelon to yields of the same nongrafted triploid watermelon cultivar that has resistance to F. oxysporum f. sp. niveum race 1 .

\section{Materials and Methods}

Rootstocks and grafting procedure. Seedless watermelon Fascination was grafted onto four rootstocks: bottle gourd 'Macis' (Nunhems USA) and 'Emphasis' (Syngenta Seeds) and interspecific hybrid squash 'Strong Tosa' and 'Carnivor' (Syngenta Seeds). Seeding of the different cultivars was staggered to ensure that the hypocotyls of all varieties were the appropriate diameter $(3 \mathrm{~mm})$ when grafted, and rootstocks were at the appropriate developmental stage (tip of the first true leaf just beginning to emerge) to minimize regrowth of the tops of rootstocks, as described previously $(10,14)$. When the watermelon scion was at the first true-leaf stage, watermelon was grafted onto the rootstocks using the one-cotyledon grafting method on 2 March 2012 and 15 March 2013 (10). Grafted plants were placed in a healing chamber with $90 \%$ relative humidity for 1 week and then transferred to a greenhouse until field transplanting. In order to determine whether the grafting procedure had an effect on infection by $F$. oxysporum f. sp. niveum, a self-grafted control treatment was included, in which Fascination seedlings were used both as the scion and the rootstock (28). Grafted plants and nongrafted Fascination plants used as another susceptible control treatment were transplanted to the fields on 26 March 2012 and 3 April 2013.

Experimental sites. The experiment in 2012 was done on a large, commercial watermelon farm in South Carolina as a demonstration of grafting. The soil type was Autryville fine sand (loamy, siliceous, subactive, thermic Arenic Paleudults) with a $\mathrm{pH}$ of 6.1. The field was planted to watermelon every other year; in 2011 it was planted to corn (Zea mays). The portion of the field used for the experiment was severely infested with $F$. oxysporum f. sp. $n i$ veum race 2 (12). Only race 2 isolates were recovered from 17 diseased plants sampled in 2008 (13). Average maximum and minimum temperatures for April, May, and June 2012 were 26.3 and 12.6, 29.5 and 17.9 , and 30.2 and $18.5^{\circ} \mathrm{C}$, respectively. Total precipitation for April, May, and June 2012 was 57.9, 175.3, and $107.2 \mathrm{~mm}$, respectively. Minimum temperatures in April and May were 3 to $4^{\circ} \mathrm{C}$ warmer and maximum temperatures in June were 2 to $3^{\circ} \mathrm{C}$ cooler than the 30 -year normal. Rainfall in April and June was less than the 30-year normal but, in May, it was 2.6 times greater.

In 2013, the experiment was repeated at the Clemson University Coastal Research and Education Center (CREC) $\left(32^{\circ} 47^{\prime} 30.4 \mathrm{~N}\right.$; $80^{\circ} 4^{\prime} 11.16 \mathrm{~W}$ ). The research station site was chosen so that additional yield data could be collected. The soil type was Yonges loamy fine sand (fine-loamy, mixed, active, thermic Typic Endoaqualfs) with a $\mathrm{pH}$ of 6.2. The field had been cropped to watermelon yearly since 2005 and was planted to rye (Secale cereale) in fall 2012. F. oxysporum f. sp. niveum races 1 and 2 were present in this field (12). In 2005, race 1 and race 2 isolates were recovered from 14 and 21 plants sampled, respectively. In spring 2010, the field was reinfested with a 1:1 mixture of a race 1 isolate and a race 2 isolate collected from the field in 2005 (14). Average maximum and minimum temperatures for April, May, June, and July 2013 were 23.2 and 12.2, 26.3 and 16.1, 30.1 and 21.8, and 29.9 and $22.8^{\circ} \mathrm{C}$, respectively. Maximum temperatures in each month were 1 to $2^{\circ} \mathrm{C}$ cooler than the 50-year normal. Rainfall for April, May, June, and July 2013 was 134.6, 49.5, 361.7, and $71.4 \mathrm{~mm}$, respectively. Rainfall was below the 50 -year normal for May and July and 1.9 and 2.4 times greater in April and June, respectively.

Field plot establishment and maintenance. Both experiments were set up in a randomized, complete block design with five replications. In 2012, each plot was a single row, $38.1 \mathrm{~m}$ long, with 50 plants spaced $0.76 \mathrm{~m}$ apart within the row. In 2013, each plot was a single row, $15.2 \mathrm{~m}$ long, with 16 plants spaced $0.9 \mathrm{~m}$ apart within the row. Plots were separated within rows by $3.0 \mathrm{~m}$ of unplanted area. The pollenizer watermelon lines 'SP5' and 'SP6' (Syngenta Seeds) that are resistant to $F$. oxysporum $\mathrm{f}$. sp. niveum race 1 were planted between every third plant within plots in 2012 and 2013, respectively.

In 2012, the field was prepared by the cooperating grower by disking, subsoiling, and applying lime at $1.12 \mathrm{Mg} / \mathrm{ha}$ and a preplant granular 40N-50P-90K fertilizer. On 23 January 2012, raised beds were shaped $0.45 \mathrm{~m}$ wide on $2.2-\mathrm{m}$ centers and covered with black polyethylene mulch. Liquid $7 \mathrm{~N}-2 \mathrm{P}-7 \mathrm{~K}$ fertilizer was injected through the drip irrigation system on 23 and 30 April 2012. Liquid $8 \mathrm{~N}-0 \mathrm{P}-8 \mathrm{~K}$ fertilizer was used from 7 May to 17 July 2012; the volume of fertilizer injected was adjusted weekly based on soil and plant nutrient analyses. Soluble boron at 1.2 liters/ha and calcium nitrate at 1.75 liters/ha were applied weekly the entire season. Soluble manganese at 1.2 liters/ha and magnesium nitrate at 1.2 to 2.3 liters/ha were applied weekly from 2 May to 8 June 2012 . Fungicides and insecticides were applied first on 9 April 2012 and then every 7 to 10 days from 2 May until 19 July (fungicides) or 5 July (insecticides) 2012. Fungicides applied included chlorothalonil (formulation unknown), mancozeb (Manzate Pro-Stick 75DG, 1.3 to $2.5 \mathrm{~kg} / \mathrm{ha}$ ), tebuconazole (Monsoon $3.6 \mathrm{~F}, 0.25 \mathrm{~kg} / \mathrm{ha}$ ), tebuconazole plus fluopyram (Luna Experience 400SC, $0.29 \mathrm{~kg} / \mathrm{ha}$ ), cyprodinil plus difenoconazole (Inspire Super 2.82SC, $0.49 \mathrm{~kg} / \mathrm{ha}$ ), and cuprous oxide (Nordox 75WG, $0.42 \mathrm{~kg} / \mathrm{ha}$ ).

To prepare the field in 2013, it was disked twice. On 7 March 2013, raised beds were shaped $0.9 \mathrm{~m}$ wide on $2.7-\mathrm{m}$ centers, and $10 \mathrm{~N}-10 \mathrm{P}-10 \mathrm{~K}$ fertilizer at $560 \mathrm{~kg} / \mathrm{ha}$ was banded within the row. Raised beds were formed, sprayed with the herbicide $\mathrm{S}$ metolachlor (Dual Magnum 7.62EC) at $2.13 \mathrm{~kg} / \mathrm{ha}$, and then covered with black polyethylene mulch. Alleys between raised beds were sprayed with S-metolachlor on 22 March. Liquid 8-0-8 fertilizer was applied to the field throughout the season through the drip irrigation system (15). Insects and mites were managed with applications of dinotefuran (Venom 70SG, $0.20 \mathrm{~kg} / \mathrm{ha}$ ) on 3 May and 5 June, abamectin (Agrimek 0.15EC, $0.28 \mathrm{~g} / \mathrm{ha}$ ) on 5 June, and bifenthrin (Brigade 2EC, $0.11 \mathrm{~kg} / \mathrm{ha}$ ) on 26 June 2013. To prevent gummy stem blight, the fungicide cyprodinil plus difenoconazole (Inspire Super $2.82 \mathrm{SC}, 0.49 \mathrm{~kg} / \mathrm{ha}$ ) was applied on 3 May and chlorothalonil (Bravo WeatherStik $720 \mathrm{SC}, 1.7 \mathrm{~kg} / \mathrm{ha}$ ) was applied on 5, 19, and 26 June 2013. To prevent downy mildew, propamocarb (Previcur Flex 6SL at $1.0 \mathrm{~kg} / \mathrm{ha}$ ) was applied on 19 June and, to prevent anthracnose, boscalid plus pyraclostrobin (Pristine $38 \mathrm{WG}, 0.49 \mathrm{~kg} / \mathrm{ha}$ ) was applied on 3 July 2013.

Data collection. Disease incidence was determined by counting the number of plants with symptoms of wilted or dead vines and the number of dead plants in each plot (13-15). Incidence was determined at 21, 42, and 63 days after transplanting (DAT) on 12 April, 3, and 24 May 2012 and 21, 35, 42, 49, 63, and 70 DAT from 24 April through 10 June 2013.

At 12 weeks after transplanting (approximately 84 DAT) on 14 June 2012 and 1 July 2013, all fruit in all plots were counted by size, either small or large. Large fruit were estimated to weigh $\geq 6.8$ $\mathrm{kg}$ and small fruit were estimated to weigh $\leq 2.3 \mathrm{~kg}$ apiece. In 2013 only, fruit also were harvested, counted, and weighed on 1,9 , and 16 July. Fruit weighing $\geq 6.8 \mathrm{~kg}$ apiece were considered marketable (27). Fruit were not harvested in 2012, because the agreement with 
the grower was that, in exchange for using the land, he could harvest the fruit. Fruit weight in 2012 was calculated from fruit counts; large fruit were estimated to weigh $7.26 \mathrm{~kg}$ apiece, based on the cultivar description for Fascination (Syngenta Seeds), and small fruit were estimated to weigh $2.3 \mathrm{~kg}$ apiece.

Statistical analysis. Area under the disease progress curve (AUDPC) was calculated from wilt incidence ratings (29). Disease and yield data were analyzed with a mixed-model maximum likelihood analysis (PROC MIXED, SAS version 9.3; SAS Institute, Inc.), with treatment as a fixed effect and block as a random effect. Before analysis, disease incidence and survival percentages were transformed with arcsine of the square root, and some fruit counts were transformed with square root to correct for non-normality and inequality of variances among treatments. Residuals from analysis of variance were checked for non-normality and inequality of variance with PROC UNIVARIATE. Back-transformed least-squares means are shown in the tables. Treatment means were compared with $t$ tests. Preplanned, single-degree-of-freedom contrasts were used to compare rootstock genera and to compare grafted rootstocks with control watermelon treatments. Pearson correlation coefficients were calculated for all disease incidence ratings, AUDPC values, and percent survival with all yield measurements for each year. When data from the two experiments were combined, year, treatment, and the year-treatment interaction were tested as fixed effects and block within year as a random effect. The Slice Option was used to examine treatment-time interactions for wilt incidence and treatment-year interactions.

\section{Results}

Incidence of Fusarium wilt. In both experiments, disease progress for the two control treatments, nongrafted and self-grafted Fascination, followed a saturation curve, the typical shape for a monocyclic pathogen like $F$. oxysporum f. sp. niveum (Fig. 1). In both experiments, the treatment-time interaction was highly significant $(P<0.0001)$, because treatments did not differ at the first rating date (0 and 21 DAT in 2012 and 2013, respectively) but treatments differed at all subsequent rating dates. At 42 and 63 DAT in 2012 and 35, 42, 49, 63, and 70 DAT in 2013, the two control treatments had greater wilt incidences than the four rootstock treatments $(P<0.01)$. At 63 DAT the four rootstock treatments did not differ from each other (Fig. 1). At 21 and 42 DAT in 2012 only, wilt incidence for Emphasis was greater than for Strong Tosa, Carnivor, and Macis $(P \leq 0.004$ and $P<0.03$ at 21 and 42 DAT, respectively) but no other rootstock treatments differed significantly. This was the only rating date in either experiment when rootstock cultivars differed from each other.

In 2012, wilt incidence in the two control treatments increased between 0 and 21 and between 21 and 42 DAT (Fig. 1). At 63 DAT, wilt incidence in the self-grafted treatment did not differ from wilt incidence at 42 DAT, whereas wilt incidence in the nongrafted treatment was less than at $42 \mathrm{DAT}(P=0.0004)$. Wilt incidence for grafted Carnivor and Macis plants did not differ between any rating dates $(P \geq 0.20)$. Wilt incidence for grafted Strong Tosa plants differed only between 0 and 63 DAT $(P=0.0066)$. Wilt incidence for grafted Emphasis plants increased between 0 and 21 DAT $(P<$ 0.0001 ) and then did not change.

In 2013, results generally were similar to results in 2012, except that there was a lag of approximately 21 days until plants began to grow and symptoms began to appear, because weather after transplanting was wetter and cooler than normal. At the first rating at 21 DAT, only two plants had grown vines, and two nonvining plants were wilted, one each in the self-grafted and Emphasis treatments (Fig. 1). Wilt incidence in the two control treatments increased from 21 to 42 DAT $(P \leq 0.0008$ for self-grafted and $P=0.0374$ for nongrafted plants) and then did not change significantly for the rest of the season, except that wilt incidence at 70 DAT for nongrafted plants was greater than at 42 DAT $(P=0.015)$. Self-grafted plants had a greater incidence than nongrafted plants at 42 and 49 DAT $(P$ $\leq 0.04)$. Wilt incidence for grafted Carnivor, Strong Tosa, and Emphasis plants did not differ over time $(P \geq 0.46)$. Wilt incidence for grafted Macis plants increased between 21 and 35 DAT $(P<0.009)$ and then did not change.

To determine the effects of grafting on the rate of disease progress, the linear slopes of the disease progress curves between 21 and 42 DAT were calculated and compared. The year-treatment interaction was significant $(P=0.007)$, because slopes for nongrafted Fascination differed between years $(P=0.0001)$ but slopes for other treatments did not differ between years $(P \geq 0.13)$. In both years, the slopes for the two control treatments were greater than for the grafted rootstock treatments, and the slopes for the rootstock treatments did not differ from each other (Table 1). In the nongrafted treatment, a mean of 3.1 additional plants showed

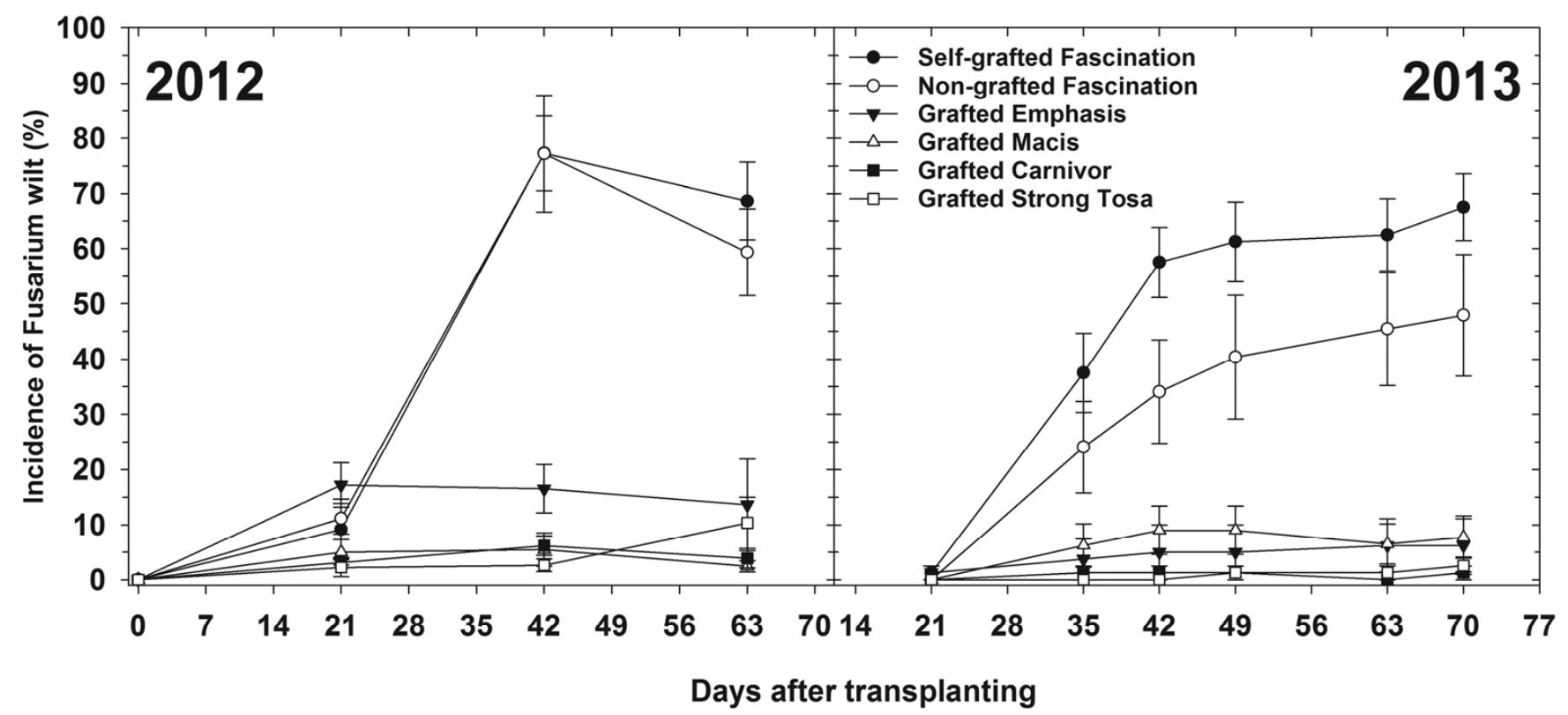

Fig. 1. Progress of Fusarium wilt in 2012 and 2013 on triploid watermelon 'Fascination', which is resistant to Fusarium oxysporum f. sp. niveum race 1. Fascination was not grafted, self-grafted, or grafted onto two bottlegourd rootstocks, 'Emphasis' and 'Macis', and two interspecific hybrid squash rootstocks, 'Carnivor' and 'Strong Tosa'. Each data point is the mean of five replications with one standard error of the mean. In both years, nongrafted and self-grafted treatments differ significantly from all four grafted rootstock treatments at all rating dates after the first rating $(P<0.01)$. 
symptoms of wilting each day between 21 and 42 DAT in 2012, a rate that was approximately twice as fast as in the 2013 epidemic (Table 1). By 42 DAT, grafted plants were much larger and more vigorous than nongrafted plants (Fig. 2). In 2013 only, the slope for the nongrafted Fascination treatment was less than for the selfgrafted Fascination treatment (Table 1).

Wilt incidence at 63 DAT and AUDPC were similar in both experiments, because there were no year-treatment interactions $(P=$ 0.57 for incidence and $P=0.11$ for AUDPC). Disease incidence and AUDPC were greater in 2012 than in 2013 (year main effects significant at $P=0.0144$ for incidence and $P<0.0001$ for AUDPC; Fig. 1). As with the measurements of disease progress presented previously, the two control treatments had greater mean incidence and mean AUDPC values than the grafted rootstock treatments, and the four rootstocks did not differ from each other (Table 1). In addition, the two control treatments did not differ from one another.

Plants on which scions died because of a break in the graft union were not included in the wilt incidence calculations. In 2012, 0 to 5 plants were missing at the first rating at 21 DAT. Because dead plants were not present, these plants also were not included in the wilt incidence calculations, although some of them might have died from Fusarium wilt. At 63 DAT, a mean of 1.3 to 4.7 plants were missing or had dead scions on healthy rootstocks across the six treatments but there was no difference among treatments ( $F$ not significant, $P=0.14$ ). In 2013, only 4 of 320 scions died on plants with intact, living rootstocks: 3 scions and 1 scion on plants grafted onto Macis and Strong Tosa, respectively. One nongrafted plant also was lost during the experiment. No plants were lost after 42 DAT in 2013.

Percent survival of plants (i.e.. the percentage of living healthy or diseased plants) differed between years for the interspecific hybrid squash rootstocks. The year-treatment interaction was significant $(P=0.0029)$, because survival of interspecific hybrid squash Carnivor and Strong Tosa was less in 2012 than in $2013(P$ $\leq 0.003$ ), but survival for the other treatments did not differ significantly between years $(P \geq 0.07)$ (Table 1$)$. In 2012 , percent survival of grafted Emphasis and Macis was greater than nongrafted Fascination and, in 2013, percent survival of all grafted plants was $\geq 95 \%$ and greater than both susceptible control treatments. Within years, percent survival did not differ among the four rootstocks.

Yields of triploid watermelon fruit. In both experiments, the numbers of large (or marketable) and small (nonmarketable) fruit were counted at 12 weeks after transplanting. For large fruit, there was a significant treatment-year interaction $(P=0.0077)$, because all four grafted rootstocks produced more fruit in 2012 than in 2013 ( $P \leq 0.01)$, but the two susceptible control treatments of nongrafted and self-grafted Fascination did not differ between years $(P \geq 0.31)$. In both years, watermelon grafted onto Macis and Strong Tosa produced more large fruit than the two susceptible control treatments $(P \leq 0.02$; Table 2$)$. In addition, watermelon grafted onto Carnivor and Emphasis produced more large fruit than the two susceptible control treatments in $2012(P \leq 0.01)$, and grafted Carnivor produced more large fruit than the self-grafted control in $2013(P=0.0391)$. In 2013, watermelon grafted onto Strong Tosa produced more fruit than when grafted onto Emphasis $(\mathrm{P}=0.0267)$. In 2012, nongrafted and self-grafted Fascination plants produced more small fruit than grafted Emphasis and Macis $(P \leq 0.04)$, and self-grafted Fascination produced more small fruit than grafted Carnivor and Strong Tosa $(P \leq 0.03)$ (Table 2). In 2013, the number of small fruit did not differ among treatments.

The total number of fruit counted at 12 weeks after transplanting was greater in 2012 than in $2013(P<0.0001)$ but there was no treatment-year interaction $(P=0.86)$. Watermelon grafted onto Macis and Strong Tosa produced more fruit than the two susceptible control treatments (Table 2). For percent marketable fruit, there was a marginally significant treatment-year interaction $(P=$ 0.0584). Nongrafted Fascination produced more large fruit in 2013 $(49.3 \%)$ than in $2012(21.6 \%)(P=0.0157)$ but there was no significant difference between years for the other five treatments $(P \geq$

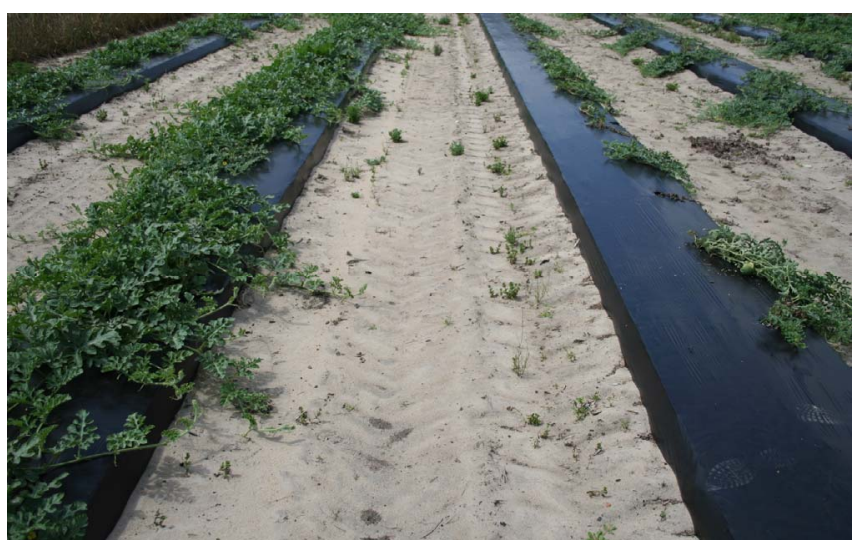

Fig. 2. Grafted (left row) and nongrafted (right row) triploid 'Fascination' watermelon 42 days after transplanting into a field infested with Fusarium oxysporum f. $\mathrm{sp}$. niveum race 2 on a commercial farm in South Carolina.

Table 1. Progression and incidence of Fusarium wilt and percentage survival with triploid watermelon 'Fascination' grafted onto four different rootstocks in 2012 and 2013

\begin{tabular}{|c|c|c|c|c|c|c|c|}
\hline \multirow[b]{2}{*}{ Rootstock $^{x}$} & \multirow[b]{2}{*}{ Treatment } & \multicolumn{2}{|c|}{ Linear rate of disease increase $^{v}$} & \multirow[b]{2}{*}{ Wilt (\%)y } & \multirow[b]{2}{*}{$\mathbf{A U D P C}^{\mathrm{z}}$} & \multicolumn{2}{|c|}{ Plant survival $(\%)^{\mathrm{w}}$} \\
\hline & & 2012 & 2013 & & & 2012 & 2013 \\
\hline Fascination & Self-grafted & $0.0324 \mathrm{a}$ & $0.0268 \mathrm{a}$ & $66.3 \mathrm{a}$ & $2,240.2 \mathrm{a}$ & $81.2 \mathrm{bc}$ & $64.6 \mathrm{~b}$ \\
\hline None & Nongrafted & $0.0315 \mathrm{a}$ & $0.0162 \mathrm{~b}$ & $52.4 \mathrm{a}$ & $1,837.8 \mathrm{a}$ & $72.9 \mathrm{c}$ & $73.1 \mathrm{~b}$ \\
\hline Emphasis & Grafted & $-0.0003 \mathrm{~b}$ & $0.0018 \mathrm{c}$ & $5.9 \mathrm{~b}$ & $328.3 \mathrm{~b}$ & $93.5 \mathrm{ab}$ & $99.2 \mathrm{a}$ \\
\hline Macis & Grafted & $0.0002 \mathrm{~b}$ & $0.0043 \mathrm{c}$ & $2.7 \mathrm{~b}$ & $165.4 \mathrm{~b}$ & $97.5 \mathrm{a}$ & $95.1 \mathrm{a}$ \\
\hline Carnivor & Grafted & $0.0015 \mathrm{~b}$ & $0.0006 \mathrm{c}$ & $0.7 \mathrm{~b}$ & $70.6 \mathrm{~b}$ & $90.2 \mathrm{abc}$ & $100.0 \mathrm{a}$ \\
\hline Strong Tosa & Grafted & $0.0002 \mathrm{~b}$ & $0.0000 \mathrm{c}$ & $2.7 \mathrm{~b}$ & $73.3 \mathrm{~b}$ & $86.8 \mathrm{abc}$ & 99.7 a \\
\hline$P$ value for treatment & $\ldots$ & $<0.0001$ & $<0.0001$ & $<0.0001$ & $<0.0001$ & 0.0034 & $<0.0001$ \\
\hline
\end{tabular}

${ }^{\mathrm{v}}$ Linear rate of disease increase between 21 and 42 days after transplanting (DAT) (proportion of plants infected/day). The year-treatment interaction was significant $(P=0.007)$, because slopes for the nongrafted Fascination treatments were less in 2013 than in $2012(P=0.0001)$ but slopes for the other treatments did not differ significantly between years $(P \geq 0.13)$. Least-squares means within a column followed by the same letter are not significantly different based on $t$ tests at $P \leq 0.01$.

${ }^{w}$ Percentage of surviving (healthy plus diseased) plants. Least-squares means back-transformed from square root values used in the analysis of variance. The year-treatment interaction was significant $(P=0.0029)$, because survival of Carnivor and Strong Tosa were less in 2012 than in $2013(P \leq 0.003)$ but survival for the other treatments did not differ significantly between years $(P \geq 0.07)$. Means calculated across years within a column followed by the same letter are not significantly different based on $t$ tests at $P \leq 0.01$.

${ }^{x}$ Rootstocks Emphasis and Macis are bottle gourd and Strong Tosa and Carnivor are interspecific hybrid squash.

y Wilt incidence (Wilt) at 63 DAT. Least-squares means back-transformed from arcsine of the square root values used in the analysis of variance. Means calculated across years within a column followed by the same letter are not significantly different based on $t$ tests at $P \leq 0.0001$.

${ }^{\mathrm{z}}$ AUDPC to 63 DAT. Least-squares means back-transformed from square root values used in the analysis of variance. Means calculated across years within a column followed by the same letter are not significantly different based on $t$ tests at $P \leq 0.01$. 
0.12). All four grafted rootstocks produced significantly more large fruit (60 to $113 \%$ more) than the two susceptible control treatments (Table 2).

In 2013, there was no significant difference between the number of fruit harvested and the total number of fruit counted at 12 weeks after transplanting (paired $t$ test, $P=0.43$ ). In addition, these two measurements of the number of fruit were highly correlated with each other $(r=0.775, P<0.0001)$. Thus, in 2013, essentially all fruit counted at 12 weeks after transplanting reached marketable size by the last of the three weekly harvests at 14 weeks after transplanting (Tables 2 and 3).

In 2013, there was a highly significant correlation between fruit number determined at harvest and fruit weight $(r=0.963, P<$ 0.0001 ), which has been observed previously with other cultivars of watermelon (A. P. Keinath, unpublished) (Table 3). In 2012, estimated fruit weight was greater for all four grafted rootstocks than the two susceptible control treatments $(P<0.01$ for Emphasis, Macis, and Strong Tosa and $P<0.03$ for Carnivor; Table 3). In 2012 and 2013, based on preplanned, single-degree-of-freedom contrasts, mean weight and number of fruit produced by watermelon grafted onto Carnivor and Strong Tosa, the two interspecific hybrid squash rootstocks, was greater than mean yields of the two susceptible control treatments $(P \leq 0.02$; Table 3$)$. Mean yields with grafted interspecific hybrid squash did not differ from grafted bottle gourd, which did not differ from the susceptible controls.
Pearson correlation coefficients were calculated for all disease incidences, AUDPC values, and percent survival with all yield measurements for each year. In both years, the count of large fruit, percent marketable-size fruit, and marketable weight was negatively correlated with disease incidence at or after 42 DAT and AUPDC $(P<0.01$; Table 4$)$. In addition, small fruit count was positively correlated with disease incidence in 2012; total fruit count was negatively correlated with disease incidence in 2013 ; and the count of large fruit, total fruit count, percent marketablesize fruit, and marketable weight were positively correlated with percent plant survival in $2013(P<0.01)$.

\section{Discussion}

Disease progression and maximum incidence of Fusarium wilt were similar on the commercial farm in 2012 and at the research station in 2013, despite several differences between the two sites and the two growing seasons. The population of $F$. oxysporum $\mathrm{f}$. $\mathrm{sp}$. niveum on the commercial farm was composed of race 2 whereas, at CREC, the population was previously determined to be a mixture of races 1 and $2(12,13)$. Thus, approximately one-half to two-thirds of the chlamydospores of $F$. oxysporum $\mathrm{f}$. sp. niveum could cause wilt on the nongrafted and self-grafted plants in 2013, whereas essentially $100 \%$ of the population could in 2012 .

The plant-available water in the two experiments likely differed substantially, based on soil type and amount of precipitation. The

Table 2. Numbers of triploid watermelon fruit counted and grouped by size based on estimated weight, 12 weeks after transplanting in 2012 and 2013

\begin{tabular}{|c|c|c|c|c|c|c|c|}
\hline \multirow[b]{3}{*}{ Rootstock } & \multirow[b]{3}{*}{ Treatment } & \multicolumn{4}{|c|}{ Fruit/ha $(n)^{\mathbf{u}}$} & & \\
\hline & & \multicolumn{2}{|c|}{2012} & \multicolumn{2}{|c|}{2013} & \multicolumn{2}{|c|}{ 2012-2013 } \\
\hline & & Large $^{v}$ & Small $^{w}$ & Large $^{x}$ & Small & Total fruit/ha $(n)^{y}$ & Marketable-size $(\%)^{\mathrm{z}}$ \\
\hline Fascination & Self-grafted & $1,834 \mathrm{~b}$ & $6,420 \mathrm{a}$ & $1,913 \mathrm{~d}$ & 1,446 & $5,577 \mathrm{~b}$ & $34.8 \mathrm{~b}$ \\
\hline None & Nongrafted & $2,669 \mathrm{~b}$ & $5,694 \mathrm{ab}$ & $2,056 \mathrm{~cd}$ & 1,767 & $5,851 \mathrm{~b}$ & $40.5 \mathrm{~b}$ \\
\hline Emphasis & Grafted & $7,367 \mathrm{a}$ & $3,361 \mathrm{c}$ & $2,726 \mathrm{bcd}$ & 813 & $6,788 \mathrm{ab}$ & $74.1 \mathrm{a}$ \\
\hline Macis & Grafted & $9,014 \mathrm{a}$ & $3,140 \mathrm{c}$ & $3,395 \mathrm{ab}$ & 1,879 & 8,447 a & $69.7 \mathrm{a}$ \\
\hline Carnivor & Grafted & $6,081 \mathrm{a}$ & $3,640 \mathrm{bc}$ & $3,060 \mathrm{abc}$ & 1,596 & $7,204 \mathrm{ab}$ & $65.0 \mathrm{a}$ \\
\hline Strong Tosa & Grafted & $7,933 \mathrm{a}$ & $3,828 \mathrm{bc}$ & $3,969 \mathrm{a}$ & 1,313 & $8,265 \mathrm{a}$ & $71.0 \mathrm{a}$ \\
\hline$P$ value for treatment & $\ldots$ & 0.0058 & 0.0298 & 0.0058 & 0.4506 & 0.0048 & $<0.0001$ \\
\hline \\
\hline \multicolumn{8}{|c|}{ v Least-squares means within a column followed by the same letter are not significantly different based on $t$ tests at $P \leq 0.01$. } \\
\hline \multicolumn{8}{|c|}{$\begin{array}{l}\text { w Least-squares means back-transformed from square root values used in the analysis of variance. Means within a column followed by the same letter are not } \\
\text { significantly different based on } t \text { tests at } P \leq 0.05 \text {. }\end{array}$} \\
\hline \multicolumn{8}{|c|}{${ }^{x}$ Least-squares means within a column followed by the same letter are not significantly different based on $t$ tests at $P \leq 0.05$} \\
\hline \multicolumn{8}{|c|}{$\begin{array}{l}\text { y Mean total number of fruit per hectare. Least-squares means back-transformed from square root values used in the analysis of variance. Means within a } \\
\text { column followed by the same letter are not significantly different based on } t \text { tests at } P \leq 0.01 \text {. }\end{array}$} \\
\hline \multicolumn{8}{|c|}{$\begin{array}{l}{ }^{\mathrm{z}} \text { Mean percent marketable-size fruit. Least-squares means back-transformed from arcsine of the square root values used in the analysis of variance. Means } \\
\text { within a column followed by the same letter are not significantly different based on } t \text { tests at } P \leq 0.01 \text {. }\end{array}$} \\
\hline
\end{tabular}

Table 3. Weight and number of marketable-sized triploid watermelon fruit produced by grafted or nongrafted 'Fascination' plants in 2012 and 2013

\begin{tabular}{|c|c|c|c|c|}
\hline \multirow[b]{2}{*}{ Rootstock $^{\mathrm{x}}$} & \multirow[b]{2}{*}{ Treatment } & \multicolumn{2}{|c|}{ Fruit weight $(\mathrm{Mg} / \mathrm{ha})^{\mathrm{w}}$} & \multirow[b]{2}{*}{ Fruit/ha, $2013(n)^{\mathrm{w}, \mathrm{z}}$} \\
\hline & & $2012^{y}$ & 2013 & \\
\hline Fascination & Self-grafted & $30.76 \mathrm{~b}$ & 19.8 & 3,730 \\
\hline None & Nongrafted & $33.00 \mathrm{~b}$ & 16.9 & 2,869 \\
\hline Emphasis & Grafted & $62.16 \mathrm{a}$ & 22.9 & 3,921 \\
\hline Macis & Grafted & $73.55 \mathrm{a}$ & 29.9 & 5,069 \\
\hline Carnivor & Grafted & $54.45 \mathrm{ab}$ & 30.9 & 5,404 \\
\hline Strong Tosa & Grafted & $67.54 \mathrm{a}$ & 27.9 & 4,734 \\
\hline$P$ value for treatment & $\ldots$ & 0.0003 & 0.1276 & 0.1562 \\
\hline \multicolumn{5}{|l|}{ Preplanned comparisons ( $P$ value) } \\
\hline Grafted vs. control treatments & $\ldots$ & $<0.0001$ & 0.0138 & 0.0245 \\
\hline Bottle gourd vs. squash & $\ldots$ & 0.2902 & 0.4747 & 0.4288 \\
\hline Bottle gourd vs. control treatments & $\ldots$ & $<0.0001$ & 0.0623 & 0.1066 \\
\hline Squash vs. control treatments & $\cdots$ & 0.0002 & 0.0137 & 0.0205 \\
\hline
\end{tabular}

${ }^{\text {w }}$ Weight in 2012 was calculated from fruit counts at 12 weeks after transplanting (Table 2) by assigning a weight of $7.3 \mathrm{~kg}$ to large fruit and $2.3 \mathrm{~kg}$ to small fruit. Weight and number in 2013 were determined from mature fruit harvested 12, 13, and 14 weeks after transplanting. All fruit harvested in 2013 were marketable sized $(\geq 6.8 \mathrm{~kg})$.

${ }^{x}$ Rootstocks Emphasis and Macis are bottle gourd and Strong Tosa and Carnivor are interspecific hybrid squash. Control treatments are self-grafted (Fascination) and nongrafted (None) Fascination.

${ }^{y}$ Least-squares means within a column followed by the same letter are not significantly different based on $t$ tests at $P \leq 0.01$.

${ }^{\mathrm{z}}$ Number of fruit harvested per hectare. 
fine sand on the commercial farm has less water-holding capacity than the fine sandy loam at the research station. In addition, the weather during the experiment in 2012 was hotter and drier than normal whereas, in 2013, the opposite weather conditions prevailed, with a cooler spring and an overall wetter growing season. Plants received excess amounts of water in June 2013 due to natural rainfall that was 2.5 times the monthly average, plus the minimal amounts of irrigation needed to deliver liquid fertilizer. Despite these differences in water regimes, the size of the root systems may not have differed significantly between the two experiments. In previous research in South Carolina conducted in a sandy soil, root density of triploid watermelon did not differ among plants not grafted or grafted onto a bottle gourd or interspecific hybrid squash, or when plants were supplied with deficient or excess amounts of water (26). The impact of root growth on development and severity of Fusarium wilt of watermelon has not been determined. A larger root system could help plants tolerate Fusarium infection but it also exposes the plant to a larger number of chlamydospores in soil.

Survival of watermelon plants grafted onto bottle gourd rootstocks was greater than survival of nongrafted watermelon in both years of this study. Percent plant survival was positively correlated with fruit weight. This correlation suggests that improving plant survival and maintaining a high plant density is an important factor contributing to yield. In Oklahoma, watermelon grafted onto experimental interspecific hybrid squash and bottle gourd rootstocks had a $100 \%$ survival rate, compared with 4 to $43 \%$ survival of watermelon cultivars resistant or susceptible to race 1 , when planted into a field with a mixed population of $F$. oxysporum $\mathrm{f}$. sp. niveum races 1 and 2 in which race 1 predominated (31). In Spain, grafted watermelon had a mean survival of $93 \%$, whereas $41 \%$ of nongrafted watermelon plants survived in Fusarium-infested soil (25). Even if a few plants of grafted watermelon are lost due to breakage of the graft union or infection by Fusarium early in the season, the final plant density is significantly improved compared with susceptible watermelon cultivars.

In both experiments, there was an initial infection period when many nongrafted and self-grafted plants and a few plants grafted onto rootstocks were infected by $F$. oxysporum f. sp. niveum, and vines or scions on these plants wilted. After 35 DAT, there was no increase in wilt incidence on any rootstocks except on Strong Tosa in 2012, while wilt incidence continued to increase on the selfgrafted and nongrafted watermelon plants until $\geq 42$ DAT. Certain Cucurbita spp. or cultivars are susceptible to infection by $F$. oxysporum $\mathrm{f}$. sp. niveum in the seedling stage $(2,22,24)$. Interspecific hybrid squash and bottle gourd also were infected by $F$. oxysporum f. sp. niveum in the greenhouse and the field but nongrafted plants were symptomless after infection (14). The effect of rootstock age on resistance to infection by $F$. oxysporum $\mathrm{f}$. sp. niveum has not been determined. However, in the current study, it appeared that, as interspecific hybrid squash and bottle gourd rootstocks matured, they became highly resistant to infection. Based on progression of Fusarium wilt in this study and a previous study, 42 DAT appeared to be one of the critical times to determine wilt incidence in experiments that include grafted and nongrafted treatments (14). However, in other studies, additional susceptible plants developed wilt symptoms later in the growing season; therefore, at least one additional rating after 42 DAT is necessary $(15,31)$.

The self-grafted control treatment was included to verify that wounding the plants during grafting did not induce resistance to Fusarium spp. (28). Clearly, self-grafted plants were as susceptible as (2012) or more susceptible than (2013) the nongrafted control plants. In our previous field experiments, self-grafted 'Tri-X 313' plants were more susceptible to $F$. oxysporum f. sp. niveum in 2010 and equally susceptible in 2011 (14). Watermelon is not a suitable rootstock for watermelon, and it never has been used to graft watermelon (18). However, the reason for increased susceptibility of self-grafted plants under certain conditions is unknown.

In these two experiments, triploid watermelon Fascination grafted onto the bottle gourd Macis and the interspecific hybrid squash Strong Tosa yielded more marketable-size fruit than the nongrafted and self-grafted control treatments. When grafted with triploid watermelon Tri-X 313 in a previous study, Macis and the bottle gourd Emphasis yielded the most marketable-sized fruit (14). Thus, different rootstocks performed better with different scions, although it appears that the rootstock Macis performed most consistently in four field experiments in South Carolina. In Turkey, five cultivars of bottle gourd (one of which was Emphasis) grafted to a diploid watermelon cultivar resistant to race 1 yielded more fruit by weight than two grafted cultivars of interspecific hybrid squash (one of which was Strong Tosa) (35). However, in Spain, four cultivars of interspecific hybrid squash grafted to a triploid watermelon yielded more fruit by weight than a single cultivar of grafted bottle gourd in Fusarium-infested soil (25). Thus, different rootstocks are better suited to different environments and, therefore, must be evaluated under local growing conditions.

In fields infested with $F$. oxysporum f. sp. niveum, expected yield of grafted plants compared with nongrafted, susceptible watermelon can be up to $80 \%$ greater, based on mean fruit weight across all four rootstocks tested in this study (Table 3). The cost of grafted transplants is the major additional input required in the adoption of vegetable grafting $(4,16,18)$. Estimates of the cost of grafted watermelon transplants range from three to six times the cost of nongrafted transplants, which is $\$ 0.22$ each in South Carolina $(4,8,10,16,31)$. The mean crop value (gross receipts) of the grafted

Table 4. Pearson correlation coefficients for disease incidence (DI), area under the disease progress curve (AUDPC) values, and percent surviving plants (heading row) with yield measurements (left column) for experiments with grafted triploid watermelon Fascination in 2012 and $2013^{\mathrm{v}}$

\begin{tabular}{|c|c|c|c|c|c|c|c|c|c|c|c|}
\hline & \multicolumn{4}{|c|}{2012} & \multicolumn{7}{|c|}{2013} \\
\hline & $\begin{array}{l}\text { DI } 42 \\
\text { DAT }\end{array}$ & $\begin{array}{l}\text { DI } 63 \\
\text { DAT }\end{array}$ & AUDPC & $\begin{array}{c}\text { Survival } \\
(\%)\end{array}$ & $\begin{array}{l}\text { DI } 35 \\
\text { DAT }\end{array}$ & $\begin{array}{l}\text { DI } 42 \\
\text { DAT }\end{array}$ & $\begin{array}{l}\text { DI } 49 \\
\text { DAT }\end{array}$ & $\begin{array}{l}\text { DI } 63 \\
\text { DAT }\end{array}$ & $\begin{array}{l}\text { DI 70 } \\
\text { DAT }\end{array}$ & AUDPC & $\begin{array}{c}\text { Survival } \\
(\%)\end{array}$ \\
\hline \multirow[t]{2}{*}{ Small $^{w}$} & 0.5745 & 0.5929 & 0.4934 & -0.1594 & -0.1240 & -0.0823 & -0.0866 & -0.0319 & -0.0151 & -0.0846 & 0.0981 \\
\hline & 0.0009 & 0.0023 & 0.0143 & 0.4568 & 0.5137 & 0.6656 & 0.6491 & 0.8673 & 0.9369 & 0.6568 & 0.6061 \\
\hline \multirow[t]{2}{*}{$\operatorname{Large}^{\mathrm{x}}$} & -0.7285 & -0.7910 & -0.7440 & 0.5020 & -0.5863 & -0.5858 & -0.6012 & -0.6061 & -0.6000 & -0.6107 & 0.6808 \\
\hline & 0.0001 & 0.0001 & 0.0001 & 0.0124 & 0.0007 & 0.0007 & 0.0004 & 0.0004 & 0.0005 & 0.0003 & 0.0001 \\
\hline \multirow[t]{2}{*}{ Total } & -0.4448 & -0.5062 & -0.4738 & 0.4492 & -0.5393 & -0.5160 & -0.5308 & -0.5046 & -0.4905 & -0.5372 & 0.6010 \\
\hline & 0.0138 & 0.0116 & 0.0193 & 0.0276 & 0.0021 & 0.0035 & 0.0025 & 0.0045 & 0.0059 & 0.0022 & 0.0004 \\
\hline \multirow{2}{*}{ Market (\%) } & -0.7714 & -0.8191 & -0.7658 & 0.4904 & -0.5241 & -0.5273 & -0.5385 & -0.5715 & -0.5739 & -0.5542 & 0.5186 \\
\hline & 0.0001 & 0.0001 & 0.0001 & 0.0150 & 0.0030 & 0.0028 & 0.0021 & 0.0010 & 0.0009 & 0.0015 & 0.0033 \\
\hline \multirow[t]{2}{*}{ Weight $^{2}$} & -0.6817 & -0.7517 & -0.7017 & 0.5125 & -0.5003 & -0.4380 & -0.4661 & -0.4755 & -0.4718 & -0.4821 & 0.5855 \\
\hline & 0.0001 & 0.0001 & 0.0001 & 0.0104 & 0.0049 & 0.0155 & 0.0094 & 0.0079 & 0.0085 & 0.0070 & 0.0007 \\
\hline
\end{tabular}

${ }^{\mathrm{v}}$ DAT $=$ days after transplanting. For each parameter, Pearson correlation coefficient in top row, probability that the absolute value of the correlation coefficient is $>0$ in bottom row.

${ }^{\mathrm{w}}$ Number of fruit estimated to weigh $\leq 2.3 \mathrm{~kg}$ apiece 12 weeks after transplanting.

${ }^{\mathrm{x}}$ Number of fruit estimated to weigh $\geq 6.8 \mathrm{~kg}$ apiece 12 weeks after transplanting, which is considered to be marketable size for triploid watermelon.

${ }^{\mathrm{y}}$ Marketable size.

${ }^{\mathrm{z}}$ Weight of fruit was estimated from fruit counts in 2012 and determined by weighing each fruit harvested in 2013. 
treatments (based on the average price of $\$ 0.29 / \mathrm{kg}$ for watermelon in South Carolina between 2010 and 2012) (33) was $\$ 13,388$. The net return from grafted watermelon was calculated to be $\$ 2,785$, $\$ 2,341$, or $\$ 1,106 /$ ha if grafted transplants cost $\$ 0.66, \$ 0.75$, or $\$ 1.00$ apiece. However, if grafted transplants cost $\$ 1.30$ per plant, then only grafted Macis produced a positive net return, \$1,241/ha. The loss with nongrafted transplants grown in infested soil was $\$ 1,190 /$ ha, meaning not all of the production costs were returned. In Israel, growers have been able to reduce the number of grafted watermelon transplanted per hectare due to increased fruit production on grafted compared with nongrafted plants; this is another option for improving the cost-benefit ratio of grafted watermelon (3).

Grafting watermelon onto bottle gourd or interspecific hybrid squash rootstocks can suppress development, progression, and incidence of Fusarium wilt caused by race 2 and a mixture of races 1 and 2 and increase the number of fruit produced. Other diseases found on watermelon also may affect grafted watermelon. Bottle gourd seedlings were less susceptible to Phytophthora crown rot (caused by Phytophthora capsici) and powdery mildew (Podosphaera xanthii) than watermelon or interspecific hybrid squash (17). Seedlings of interspecific hybrid squash and bottle gourd cultivars were more susceptible to Southern root-knot nematode (Meloidogyne incognita) and equally susceptible to gummy stem blight (caused by Didymella bryoniae) as watermelon $(11,32)$. The latter two diseases can be managed with nematicides and fungicides, whereas chemical management of Fusarium wilt is less reliable $(5,13)$. Grafting appears to be a viable option to manage Fusarium wilt when cultivar resistance is inadequate, provided that the cost of grafted transplants is $\leq \$ 0.75 /$ plant or $\leq 45 \%$ of the total production costs (8).

\section{Acknowledgments}

We thank V. DuBose, M. Schaffer, R. Hayes, and Z. Snipes for technical assistance, and Syngenta Seeds and Nunhems, USA for donating seed.

\section{Literature Cited}

1. Boughalleb, N., and El Mahjoub, M. 2005. Détection des races 0, 1 et 2 de Fusarium oxysporum f. sp. niveum et leur distribution dans les régions de production de la pastèque en Tunisie. EPPO Bull. 35:253-260.

2. Caperton, C. M., Martyn, R. D., and Starr, J. L. 1986. Effects of Fusarium inoculum density and root-knot nematodes on wilt resistance in summer squash. Plant Dis. 70:207-209.

3. Cohen, R., Burger, Y., Horev, C., Koren, A., and Edelstein, M. 2007. Introducing grafted cucurbits to modern agriculture: The Israeli experience. Plant Dis. 9:916-923.

4. Davis, A. R., Perkins-Veazie, P., Sakata, Y., Lopez-Galarza, S., Maroto, J. V., Lee, S. G., Huh, Y. C., Sun, Z., Miguel, A., King, S. K., Cohen, R., and Lee, J. M. 2008. Cucurbit grafting. Crit. Rev. Plant Sci. 27:50-74.

5. Egel, D. S., and Martyn, R. D. 2007. Fusarium wilt of watermelon and other cucurbits. The Plant Health Instructor. Online publication. doi:10.1094/PHII-2007-0122-01

6. Everts, K. L., and Hochmuth, M. E. 2011. Field evaluation of triploid cultivars for resistance to Fusarium wilt of watermelon in Delaware, 2010. Plant Dis. Manage. Rep. 5:V175. Online publication. doi:10.1094/PDMR05.

7. Everts, K. L., and Hochmuth, M. E. 2012. Evaluation of triploid cultivars for resistance to Fusarium wilt of watermelon, 2011. Plant Dis. Manage. Rep. 6:V014. Online publication. doi:10.1094/PDMR06.

8. Ferreira, W. 2014. Enterprise Budgets: Watermelons—on plastic-drip irrigation-seedless. Online publication. Clemson Cooperative Extension, Clemson, SC.

9. Gonzalez-Torres R., Jimenez-Diaz R. M., and Gomez-Vazquez, J. 1988. Incidencia y distribución de las fusariosis vasculares del melón y de la sandia en Andalucia. Investigación Agraria. Prod. Prot. Veg. 3:377-392.

10. Hassell, R. L., Memmott, F., and Liere, D. G. 2008. Grafting methods for watermelon production. HortScience 4:1677-1679.

11. Keinath, A. P. 2013. Susceptibility of cucurbit rootstocks to Didymella bryoniae and control of gummy stem blight on grafted watermelon seedlings with fungicides. Plant Dis. 97:1018-1024.

12. Keinath, A. P., and DuBose, V. B. 2009. First report of Fusarium oxysporum f. sp. niveum race 2 in South Carolina watermelon fields. (Abstr.) Phyto- pathology 99:S63.

13. Keinath, A. P., and Hassell, R. L. 2009. On-farm evaluation of hairy vetch and fumigation for integrated control of Fusarium wilt on seedless watermelon. Plant Dis. Manage. Rep. 3:V035. Online publication. doi:10.1094/ PDMR03

14. Keinath, A. P., and Hassell, R. L. 2014. Control of Fusarium wilt of watermelon by grafting onto bottlegourd or interspecific hybrid squash despite colonization of rootstocks by Fusarium. Plant Dis. 98:255-266.

15. Keinath, A. P., Hassell, R. L., Everts, K. L., and Zhou, X.-G. 2010. Cover crops of hybrid common vetch reduce Fusarium wilt of seedless watermelon in the eastern United States. Plant Health Progress. Online publication. doi:10.1094/PHP-2010-0914-01-RS

16. King, S. R., Davis, A. R., Liu, W., and Levi, A. 2008. Grafting for disease resistance. HortScience 43:1673-1676.

17. Kousik, C. S., and Hassell, R. L. 2009. Evaluation of commercial watermelon rootstocks for tolerance to crown rot and powdery mildew, 2007 Plant Dis. Manage. Rep. 3:V144. Online publication. doi:10.1094/PDMR03

18. Kubota, C., McClure, M. A., Kokalis-Burelle, N., Bausher, M. G., and Rosskopf, E. N. 2008. Vegetable grafting: History, use, and current technology status in North America. HortScience 43:1664-1669.

19. Kurt, S., Dervis, S., Soylu, E. M., Tok, F. M., Yetisir, H., and Soylu, S 2008. Pathogenic races and inoculum density of Fusarium oxysporum $\mathrm{f}$. sp. niveum in commercial watermelon fields in southern Turkey. Phytoparasitica 36:107-116

20. Kwon, Y.-K., and Om, Y. H. 1998. Identification and distribution of races of Fusarium oxysporum f. sp. niveum on watermelon in Korea. Cucurbit Gen. Coop. Rep. 21:33-36.

21. Ling, N., Zhang, W., Wang, D., Mao, J., Huang, Q., Guo, S., and Shen, Q. 2013. Root exudates from grafted-root watermelon showed a certain contribution in inhibiting Fusarium oxysporum f. sp. niveum. PLoS One. Online publication. doi:10.1371/journal.pone.0063383

22. Martyn, R. 1996. Fusarium wilt of watermelon. Pages 13-14 in: Compendium of Cucurbit Diseases. T. A. Zitter, C. E. Thomas, and D. L. Hopkins, eds. American Phytopathological Society, St. Paul, MN.

23. Martyn, R. D. 1987. Fusarium oxysporum f. sp. niveum race 2: A highly aggressive race new to the United States. Plant Dis. 71:233-236.

24. Martyn, R. D., and McLaughlin, R. J. 1983. Susceptibility of summer squash to the watermelon wilt pathogen (Fusarium oxysporum f. sp. $n i$ veum). Plant Dis. 67:263-266.

25. Miguel, A., Varoto, J. V., San Bautista, A., Baizauli, C., Cebolla, V., Pascual, B., López, S., and Guardiola, J. L. 2004. The grafting of triploid watermelon is an advantageous alternative to soil fumigation by methyl bromide for control of Fusarium wilt. Sci. Hortic. Amsterdam 103:9-17.

26. Miller, G., Khalilian, A., Adelberg, J. W., Farahani, H. J., Hassell, R. L., and Wells, C. E. 2013. Grafted watermelon root length density and distribution under different soil moisture treatments. HortScience 48:1021-1026.

27. Motsenbocker, C. E., and Arancibia, R. A. 2002. In-row spacing influences triploid watermelon yield and crop value. HortTechnology 12:437-440.

28. Rivard, C. L., O'Connell, S., Peet, M. M., and Louws, F. J. 2010. Grafting tomato with interspecific rootstock to manage diseases caused by Sclerotium rolfsii and southern root-knot nematode. Plant Dis. 94:1015-1021.

29. Shaner, G., and Finney, R. E. 1977. The effect of nitrogen fertilization on the expression of slow-mildewing resistance in Knox wheat. Phytopathology 67:1051-1056

30. Snipes, Z. B., Keinath, A. P., and DuBose, V. B. 2014. Field evaluation of two rootstocks to manage Fusarium wilt in watermelon, 2013. Plant Dis. Manage. Rep. 8:V237. Online publication. doi:10.1094/PDMR08

31. Taylor, M., Bruton, B., Fish, W., and Roberts, W. 2008. Cost benefit analyses of using grafted watermelon transplants for Fusarium wilt disease control. Acta Hortic. 782:343-350.

32. Thies, J. A., Ariss, J. J., Hassell, R. L., Olson, S., Kousik, C. S., and Levi, A 2010. Grafting for management of southern root-knot nematode, Meloidogyne incognita, in watermelon. Plant Dis. 94:1195-1199.

33. United States Department of Agriculture, National Agricultural Statistics Service. 2013. Vegetables 2012 Summary (January 2013).

34. Wechter, W. P., Kousik, C., McMillan, M., and Levi, A. 2012. Identification of resistance to Fusarium oxysporum f. sp. niveum race 2 in Citrullus lanatus var. citroides plant introductions. HortScience 47:334-338.

35. Yetisir, H., Sari, N., and Yücel, S. 2003. Rootstock resistance to Fusarium wilt and effect on watermelon fruit yield and quality. Phytoparasitica 31:163-169.

36. Zhou, X. G., and Everts, K. L. 2003. Races and inoculum density of Fusarium oxysporum f. sp. niveum in commercial watermelon fields in Maryland and Delaware. Plant Dis. 87:692-698.

37. Zhou, X. G., Everts, K. L., and Bruton, B. D. 2010. Race 3, a new and highly virulent race of Fusarium oxysporum f. sp. niveum causing Fusarium wilt in watermelon. Plant Dis. 94:92-98. 